\title{
Eosinophilic fasciitis: an atypical presentation of a rare disease
}

\author{
Catia Cabra/1,2 \\ iD António Novais ${ }^{\mathbf{1}}$ \\ (iD) David Araujo ${ }^{2}$ \\ (iD) Ana Mosca ${ }^{2}$ \\ (iD) Ana Lages ${ }^{2}$ \\ D. Anna Knock ${ }^{2}$
}

1. Internal Medicine Service, Centro Hospitalar Tondela-Viseu, Viseu, Portugal 2. Internal Medicine Service, Hospital de Braga, Braga, Portugal

http://dx.doi.org/10.1590/1806-9282.65.3.326

\section{SUMMARY}

Eosinophilic fasciitis, or Shulman's disease, is a rare disease of unknown etiology. It is characterized by peripheral eosinophilia, hypergammaglobulinemia, and high erythrocyte sedimentation rate. The diagnosis is confirmed by a deep biopsy of the skin. The first line of treatment is corticotherapy.

We present a rare case of eosinophilic fasciitis in a 27-year-old woman with an atypical presentation with symmetrical peripheral edema and a Groove sign. The patient responded well to treatment with corticosteroids at high doses and, in this context, was associated with hydroxychloroquine and azathioprine. After two and a half years, peripheral eosinophilia had increased, and more of her skin had hardened. At that time, the therapy was modified to include corticoids, methotrexate, and penicillamine. It is of great importance to publicize these cases that allow us to gather experience and better treat our patients.

KEYWORDS: Fasciitis. Eosinophils. Eosinophilia. Edema/etiology.

\section{INTRODUCTION}

Eosinophilic fasciitis is a rare disease characterized by skin alterations such as scleroderma, peripheral eosinophilia, hypergammaglobulinemia, and high erythrocyte sedimentation rate. ${ }^{1}$ It more frequently involves the inferior limbs. The absence of Raynaud's phenomenon or sclerodactyly distinguishes Eosinophilic fasciitis from sclerodermia. ${ }^{1}$ Literature has described fewer than 300 cases. Shulman syndrome, as it is also known, was first described in 1974. Its etiology remains unknown. ${ }^{2}$ It affects both sexes equally, with a higher incidence among individuals of 40-50 years old and no associations of race, risk factors, or family history. ${ }^{3}$

The importance of this case is related to the rarity of the disease, its atypical presentation, and the difficulty of its treatment. The reduced number of reported cases makes it harder to approach these situations and emphasizes the importance of sharing any experience.

We present the case of a 27-year-old woman with Eosinophilic fasciitis characterized by symmetrical peripheral edema and maculopapular skin rash. 


\section{CASE REPORT}

We report the case of a 27-year-old caucasian woman who works as a secretary. She has diabetes mellitus type 1 and hypothyroidism, treated and supervised. She was sent to us because of the emergent and progressive deterioration of symmetrical peripheral edema (Figure 1), asthenia, and maculopapular pruritic rash with a 2-month evolution. She had been previously treated with insulin and levothyroxine and had no other complaints or relevant history. At the objective examination, she presented with a hardening of the subcutaneous tissue of the forearms and inferior limbs with symmetric edema, with no evidence of arthritis and a maculopapular rash on the right arm. Analytically, she presented haemoglobin of $13.1 \mathrm{~g} / \mathrm{dL}$ (11.7-15.7), leucocytes $26,3 \times 10^{\wedge} 3$ uL (4-10), eosinophils $8.7 \times 10^{\wedge} 3 \mathrm{u} / \mathrm{L}$ (33\%), plaquettes 650,000 uL (150,000-450,000); sedimentation velocity of $58 \mathrm{~mm} / \mathrm{h}(<20)$, LDH $497 \mathrm{U} / \mathrm{L}(240-480)$, reactive protein $\mathrm{C} 18,1 \mathrm{mg} / \mathrm{L}(<5)$, antinuclear antibody (ANA) 1/320, anti-dsDNA 121,9 UI/mL $(<25)$, rheumatoid factor $52 \mathrm{uI} / \mathrm{mL}(<14)$ and electrophoresis of the serum proteins with a monoclonal peak of IgG de $2920 \mathrm{mg} / \mathrm{dL}$ (700-1600). The swab of peripheral blood showed eosinophilia and lymphocytes (with no morphologic alterations), thrombocytes, and some giant plaquettes. The myelogram and bone biopsy revealed granulocytic hyperplasia with mature eosinophils. We made a nuclear resonance imaging of the right hand, which revealed diffuse thickening of the subcutaneous cell tissue, associated with edema that reached the fascias and the intermuscular planes diffusely with no clear predominance; this made it reasonable to reconsider the clinical hypothesis of fasciitis with confirmation by cutaneous biopsy (Figure 2). The deep cutaneous biopsy between the subcutaneous cell tissue and the skeletal muscle showed the involvement of the fascia by numerous polymorphonuclear eosinophils. The remaining examinations, such as capillaroscopy, manometry, breathing function proofs, echocardiogram, and computerized axial tomography of thorax, abdomen, and pelvis did not show any alterations. The examinations led us to conclude that it was eosinophilic fasciitis. The patient started pulses of methylprednisolone (500 $\mathrm{mg}$ daily for 3 days), followed by $40 \mathrm{mg}$ of oral prednisolone (slowly weaning, during four months, until reaching $10 \mathrm{mg} /$ day) as well as hydroxychloroquine $400 \mathrm{mg}$ /day and azathioprine (AZA) $150 \mathrm{mg}$ /day for 2.5 years. After that period, she displayed an in-

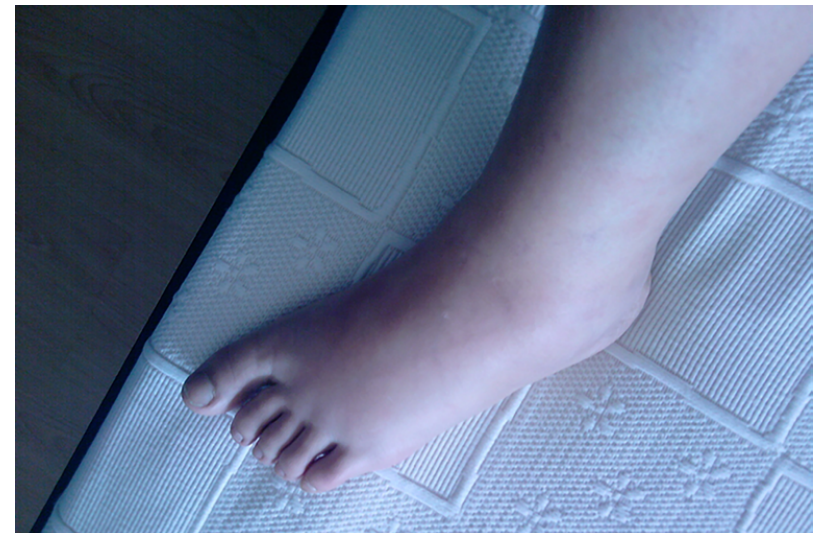

FIGURE 1: EDEMA OF THE INFERIOR MEMBER

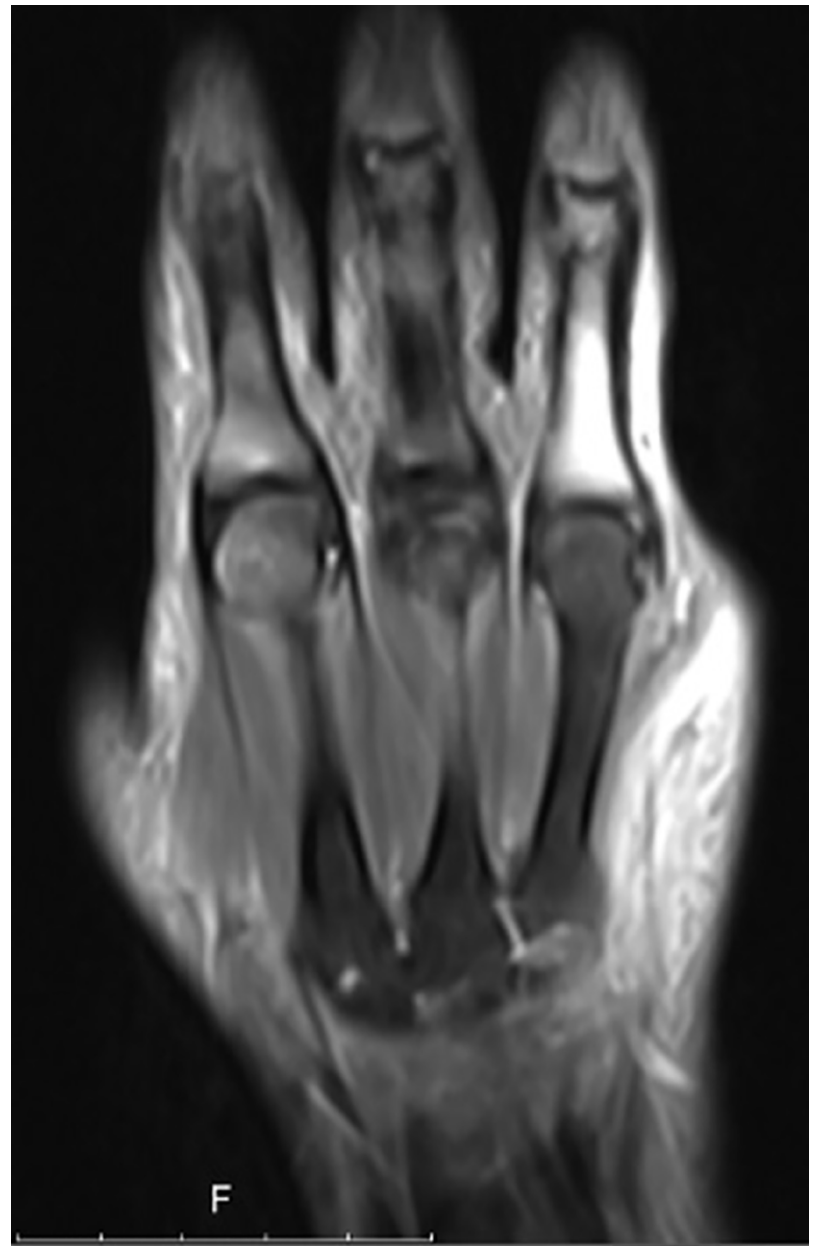

FIGURE 2: RESONANCE IMAGING OF THE RIGHT HAND

crease of peripheral eosinophils with worsening of cutaneous complaints (hardening of the skin). She repeated pulses of methylprednisolone 1gr monthly for 5 months as well as methotrexate $20 \mathrm{mg}$ /week, penicillamine $150 \mathrm{mg} /$ day, and hydroxychloroquine $400 \mathrm{mg} /$ day. One year later, there was an improvement of the subcutaneous hardening maintaining hyperpigmentation areas (figure 3 ). 


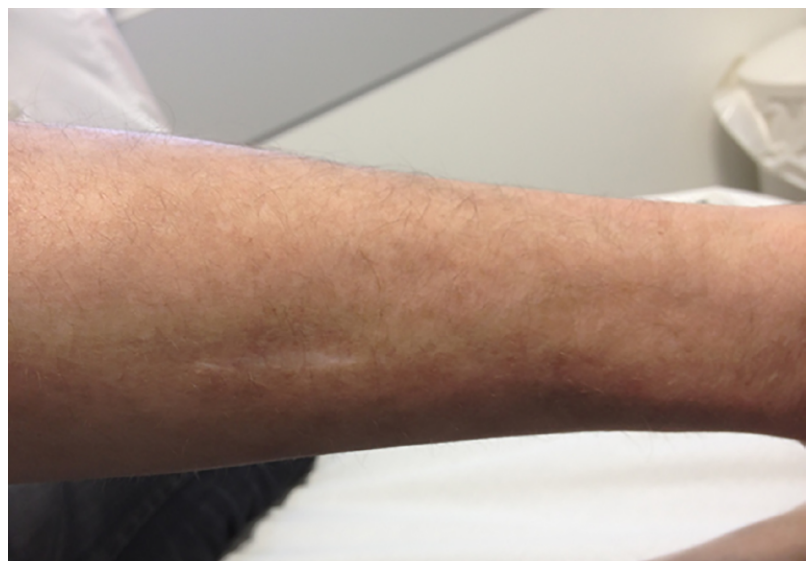

FIGURE 3: GROOVE SIGN ON THE RIGHT FOREARM

\section{DISCUSSION}

Fasciitis was first described by Shulman in $1974 .^{4}$ Its etiology remains unknown. In literature, the disease is sometimes said to have been preceded by intense physical activity. ${ }^{1}$ Some cases are associated to other factors, such as the beginning of hemodialysis, infection by Borrelia burgdorferi, radiotherapy, hematological disturbances, graft versus host disease, or medications such as simvastatin, atorvastatin, and fenitoin. ${ }^{1,5-8}$ In our case, no leading factor was detected. Serologies and cultural examinations were negative. About $15 \%$ of patients have a malign underlying disease like leukemia or lymphoma. There are also cases described as being associated with hematologic disturbances, such as aplastic anemia, hemolytic anemia, self-immune peripheric thrombocytopenia, and pernicious anemia. ${ }^{1}$ Self-immune diseases like Hashimoto Thyroiditis, morphea, systemic sclerosis, Sjögren syndrome, and antiphospholipid antibody syndrome were also reported in some patients. ${ }^{1}$ In our case, the patient has not presented any malign disease so far. She was already under treatment and supervision for type 1 diabetes mellitus and hypothyroidism.

Patients often present unspecific symptoms like weakness, general discomfort, fever, and weight loss $^{9}$. At the objective examination, we noticed a hardening of the skin (looking like "peau d'orange") with venous nodes (Groove sign) and occasionally localized morphea. ${ }^{10}$ The prayer sign is common, and the Raynaud phenomenon is not frequent. ${ }^{10}$ In this case, the patient presented a Groove sign in the right forearm and symmetric edema in the inferior limbs, which led to the differential diagnosis conditions associated to low oncotic pressure or venous failure and congestive heart failure. It was necessary to consider other differential diagnoses with similar symptoms and peripheral eosinophilia such as scleroderma, systemic sclerosis, eosinophilia-myalgia syndrome, and localized fibrosing disorders. ${ }^{5}$ Analytically, we found peripheral eosinophilia, hypergammaglobulinemia (generally IgG or IgM) and elevation of the velocity of erythrocyte sedimentation. Our patient presented peripheral eosinophilia and a peak in IgG with no specific antibody. ${ }^{9}$ The diagnosis is established by the histopathological report samples through a deep skin biopsy, which must include the muscle. Magnetic resonance imaging may prove useful to define the area for the biopsy, and later, to monitor the response of the disease to the treatment. ${ }^{1}$ The typical findings are thickening of the fascia (twice to fifteen times the normal size) associated with inflammatory cells formed by lymphocytes, plasmocytes, histiocytes and eosinophils (in 69-75\% of the cases) in variable rates. There is no necrotic vascular injury. The presence of peripheral eosinophils in the fascia is not confirmed in the diagnosis. ${ }^{9}$ Histologically, the differential diagnosis should be done with nodule erythema, Wells Syndrome and a reaction to insect bites or parasitic diseases. ${ }^{10}$

Eosinophilic fasciitis is a rare disease, which makes the treatment strategy more difficult. Corticotherapy is currently the first line of treatment at a dosage of $1 \mathrm{mg} / \mathrm{kg} /$ day until analytical normalization and clinic remission. Many patients do not answer to corticotherapy, and in the case of those who do, there may be a relapse. In these situations, other immunomodulators are used, such as azathioprine, hydroxychloroquine, cyclosporine, dapsone, and methotrexate.,10,11

The prognosis is generally good, except when an underlying malign disease is associated. Diagnosis at ages younger than 12 years, the involvement of the body, and cutaneous sclerosis such as morphea can be evidence of refractory disease. ${ }^{1}$

\section{CONCLUSION}

Eosinophilic fasciitis is a rare disease and its treatment can be a challenge. We have just presented a rare case of eosinophilic fasciitis with symmetric peripheral edema. Patients often present relapsing or do not respond to corticotherapy alone. In this case, other immunomodulator agents had to be added. It is important to spread these experiences, which allow us to gather information and knowledge to better treat and care for our patients.

There is no conflits of interesse 


\section{RESUMO}

A fasciite eosinofilica ou doença de Shulman é uma doença rara de etiologia desconhecida. É caracterizada por eosinofilia periférica, hipergamaglobulinemia e velocidade de sedimentação eritrocitária elevada. O diagnóstico é confirmado por biópsia profunda da pele. O tratamento de primeira linha é a corticoterapia.

Apresentamos um caso raro de fasciite eosinofílica numa mulher de 27 anos com uma apresentação atípica com edema periférico simétrico e sinal de Groove. A paciente respondeu bem ao tratamento com corticoides, mas em doses elevadas, e, nesse contexto, associou-se hidroxicloroquina e azatioprina. Ao fim de dois anos e meio verificou-se aumento de eosinofilia e novamente pele mais endurecida. Nessa altura alterou-se a terapêutica para corticoides, metrotexato e penicilamina. É de grande importância a divulgação desses casos que nos permitem reunir experiência e assim melhor tratar os nossos doentes.

PALAVRAS-CHAVE: Fasciite. Eosinófilos. Eosinofilia. Edemaletiologia.

\section{REFERENCES}

1. Chun $\mathrm{JH}$, Lee $\mathrm{KH}$, Sung MS, Park Cl. Two cases of eosinophilic fasciitis Ann Dermatol. 2011;23(1):81-4.

2. Massarente VL, Valadares FGC, Muzy GSC, Polônio KS. Fasciíte eosinofílica: relato de caso. Arq Med Hosp Fac Cienc Med Santa Casa São Paulo. 2017; 62(2):107-9.

3. Falcão S, Mourão AF, Ribeiro C, Pinto TL, Mateus M, Araújo $P$, et al. Fasceíte eosinofílica e aplasia medular. Acta Reumatol. Port. 2009;34(1):120-4.

4. Shulman LE. Diffuse fasciitis with eosinophilia: a new syndrome? Trans Assoc Am Physicians. 1975;88:70-86.

5. Chang CW, Lau MS. Atypical presentation of eosinophilic fasciitis with pitting edema. Hawaii J Med Public Health. 2015;74(9 Suppl 2):36-8.

6. Bischoff $L$, Derk CT. Eosinophilic fasciitis: demographics, disease pattern and response to treatment: report of 12 cases and review of the literature. Int | Dermatol. 2008;47(1):29-35.
7. Lebeaux D, Francès $C$, Barete $S$, Wechsler B, Dubourg O, Renoux |, et al. Eosinophilic fasciitis (Shulman disease): new insights into the therapeutic management from a series of 34 patients. Rheumatology (Oxford). 2012;51(3):557-61.

8. Moulton S), Kransdorf MJ, Ginsburg WW, Abril A, Persellin S. Eosinophilic fasciitis: spectrum of MRI findings. A|R Am | Roentgenol. 2005;184(3):975-

9. Lamback EB, Resende FS, Lenzi TC. Eosinophilic fasciitis. An Bras Dermatol. 2016;91(5 suppl 1):57-9.

10. Servy A, Clérici T, Malines C, Le Parc JM, Côté JF. Eosinophilic fasciitis: a rare skin sclerosis. Patholog Res Int. 2011;2011:716935.

11. Manzini CU, Sebastiani M, Giuggioli D, Manfredi A, Colaci M, Cesinaro $A M$, et al. D-penicillamine in the treatment of eosinophilic fasciitis: case reports and review of the literature. Clin Rheumatol. 2012;31(1):183-7. 